\title{
Role and Alternative Modalities of External Beam Radiotherapy in the Management of Retinoblastoma
}

\author{
Berrin PEHLIVAN, Erkan TOPKAN, Cem ONAL, Melek YAVUZ \\ Baskent University Faculty of Medicine, Adana Medical and Research Center, Kisla Campus, Adana, TURKEY
}

\begin{abstract}
Retinoblastoma (RB) is the most common orbital tumor of childhood. Treatment strategy depends on number, loalization and extent of disease (unilateral vs bilateral) involvement. Currently, significant improvements in treatment and long survival rates have been achieved in management of this tumor group that mandates for search of more sophisticated novel treatment modalities to reduce the risks of treatment related side effects and secondary malignancies. In recent years, both the role and techniques of radiation therapy (RT) have significantly changed in parallel to the improvements in technology. Present review aims to discuss the current treatment modalities in RB, and the role and alternative techniques of $\mathrm{RT}$ in the light of recent literature.
\end{abstract}

Keywords: Retinoblastoma, External beam radiotherapy, Toxicity, Chemotherapy, Secondary malignancy

\section{ÖZET}

\section{Retinoblastoma Tedavisinde Eksternal Radyoterapinin Rolü ve Radyoterapi Seçenekleri}

Retinoblastoma (RB) çocukluk çağının en sık orbital tümörü olup hastalı̆ın tedavisi tümörün sayısı, büyüklüğü, lokalizasyonu ve tutulu göz sayısına göre farkllıklar göstermektedir. Uzayan yaşam süresi ile belirginleşen radyoterapi (RT) ve/veya kemoterapiye bağ॥ yan etkilerle ikincil tümör riskini en aza indirebilecek tedavi alternatiflerinin aranmasını zorunlu kılmıştı. Diğer tedavi seçeneklerinde elde edilen başarılar sonucu eksternal RT'nin tedavideki rolündeki değişimin yanı sıra, RT tekniklerinde de teknolojiye paralel ilerlemeler kaydedilmiştir. Dolayısıyla güncel derlemede, RB tedavisinde kullanılan değişik tedavi seçenekleri ve özellikle RT'nin değişen rolü ile tekniklerinin ayrıntıı olarak tartışılması amaçlanmıştır.

Anahtar Kelimeler: Retinoblastoma, Radyoterapi, Toksisite, Kemoterapi, İkincil tümör 


\section{INTRODUCTION}

Retinoblastoma (RB) is the most common orbital tumor in children, which accounts for $5 \%$ of all childhood blindness. RB commonly occurs in younger children, usually under 2 years of age. Tumor originates from multipotential retinal cells those are capable to differentiatie into specialized photoreceptor cells. Patients may present with uni- or bilateral tumors, and genetically may be hereditary or spontaneous. Its origin and genetic involvement have been well documented. ${ }^{1,2}$

Long term survival was anecdotal for patients whom were treated at the beginning of 1900 s. However, with integration of new strategies to treatment of RB, current 5-year survival rates have been reported to exceed $95 \%$. Systematic enucleation used to be starting point of any true and structured management, until the advent of external beam radiotherapy (EBRT) made it possible not only save lives but also to retain some usefull vision. Early diagnosis has enabled focal therapies such as photocoagulation, cryocoagulation, and brachytherapy to open up a new era of targeted tumor treatment. However, the oneset of non-ocular tumors secondary to EBRT, the resistance of certain tumors to irradiation, and unsightly cosmetic consequences resulted in the continuing research into alternative therapeutic strategies. Consequently, over the past 15 years there has been an evolution in the management of RB due to earlier diagnosis and the introduction of new treatment methods. ${ }^{3-6}$ However the general lack of prospective studies there are some questions have to be answered such as which focal therapy to use with chemotherapy, what are the long-term side effects of chemotherapy, new radiation therapy modalities can be favored over chemotherapy and when we prefer EBRT and, how we treat the patients with EBRT. Present review aims to discuss the current treatment modalities in RB, and the role and alternative techniques of $\mathrm{RT}$ in the light of recent literature.

\section{HISTORY of EBRT in MANAGEMENT of RB}

Retinoblastoma is a radiosensitive tumor and RT has been one of the most efficient methods of conservative treatment approach since the beginning of twentieth century. Historically, a single "D" shaped lateral field with the anterior border placed at the outer canthus was used in RT of unilateral RB, and parallel op- posed fields for bilateral disease presentation. No well-documented dose-response relationship has been described for RB. In one study, Abramson et al. reported that the dose of RT and complication rates were directly proportional. Stallard ${ }^{8}$ proposed that a dose of at least 35 Gy in 7 days with Co-60 plaque is satisfactorily efficient in tumor control, which was later confirmed by Cassady et al. ${ }^{9}$ in a series of 230 patients series, suggesting no additional benefit of dose beyond 36 Gy except for patients with residual or recurrent RB. In contrast, dose of RT has gradually been increased based on the results of more recent studies. First, Thompson et al. ${ }^{10}$ demonstrated a relationship between the time and dose of RT and local control rates. The authors recommended a dose of 50 Gy in 5 weeks, five fractions per week. Similarly, Foote et al. ${ }^{11}$ suggested that 45 Gy in 25 fractions was sufficient for tumors up to $10 \mathrm{dd}$, but higher doses administered within a shorter treatment period was recommended for larger tumors.

Hyperfractionation has also been investigated in treatment of RB. Hayden et al. ${ }^{12}$ used a murine model to realize the value of hyperfractionated EBRT. They treated 220 eyes with a total dose ranging from 10 to 76 Gy in $1.2 \mathrm{~Gy}, 2$ Gy and 5 Gy fractions. The authors found $45 \mathrm{~Gy}$ as the tumor control dose $50 \%$ (TCD50) when administered in 2.0 Gy daily fractions. Interestingly, tumor control rate was significantly increased with twice daily $1.2 \mathrm{~Gy}$, resulting in a TCD50 of $28 \mathrm{~Gy}$.

In fractionation studies various schemes has been utilized making it difficult to compare data in radiobiological backgrounds. However, for conventional EBRT, fraction sizes greater than 2.0 Gy have been documented to be associated with severe ocular and periocular morbidity, particularly in patients treated with prior alternative methods. In an analysis of 74 patients, Parsons et al. ${ }^{13}$ reported only 1 severe retinal injury with a dose of 50 Gy or less, and all but one patient received doses 60 Gy (1.7 - 2 Gy per fraction) developed severe retinal injury, and the shape of the sigmoid dose-response curve was apparently steep between 50-60 Gy. In another study, Egawa et al. ${ }^{14}$ reported that no significant bone growth suppression was evident when dose to orbital structures kept below 12.6 Gy. Another RT-induced complication is the risk of RT-related second cancers which have been reported to be as high as 54\% at a median follow-up of 23.7 years. ${ }^{15}$ In this setting, to an effort to decrease 
the rates of both bony growth retardation and second cancers, recommended daily dose for bony orbit is less than $1 \mathrm{~Gy}{ }^{16}$

The stage and size of tumor are other crucial factors which may significantly alter prescribed total dose of RT and resultant tumor control rates (Table 1). Although the Reese-Ellsworth (RE) staging system is helpful in deciding RT volume and dose, it is challenged with having no recommendation on importance of localized vs. diffuse vitreous seeding, which is an another important prognostic factor in management of Group V disease. ${ }^{19,22}$ Despite all difficulties in RT of $\mathrm{RB}$, relatively good local control rates of approximately $70 \%$ has been achieved with integration of EBRT into multidisciplinary management of RB, currently with salvage modalities overall useful ocular survival is approximately $80 \%$ (Table 2 ).

\section{CANCER INDICENCE}

Etiologically, the mutation in the RB gene on chromosome $13 q 14$ is responsible from the development of $\mathrm{RB}$, product of which is one of the most important proteins that is crucial for regulation of cell cycle. Hereditary RB patients are gene carriers in whom one of the two RB genes possesses a mutation in all somatic cells. While patients with sporadic unilateral $\mathrm{RB}$ are suggested to have no increased risk for second malignancies, $80 \%$ of hereditary RB are bilateral and are additionally associated with increased risk of second malignancies. It has been well demonstrated that EBRT can induce the development or enhance the risk for second malignancies specifically in children with bilateral disease via increased somatic mutations caused by ionizing radiation. Therefore, these patients are also under the risk of various other tumors including osteosarcomas, soft tissue sarcomas, brain tumors, etc. In a large study including 1506 patients, Abramson et al. ${ }^{22}$ reported a significant increase in second non-ocular tumors among patients treated with EBRT before the age of 12 months. They found an increased risk for soft tissue and bone tumors of the head in patients treated with EBRT, but this risk disappeared in comparisons between the patients treated with EBRT after the age of 12 months and those who did not receive RT. Additionally, no significant difference between groups was reported in terms of second tumors arising at extraRT port sites.

\begin{tabular}{|c|c|}
\hline Series & Local Control (\%) \\
\hline \multicolumn{2}{|l|}{ Cassady et al (9) } \\
\hline Groups I-III & $73 \%$ \\
\hline GroupsIV-V & $20 \%$ \\
\hline \multicolumn{2}{|c|}{ McCormick et al (17) } \\
\hline Groups I-III & $83 \%$ \\
\hline GroupsIV-V & $35 \%$ \\
\hline \multicolumn{2}{|l|}{ Egbert et al ( 18) } \\
\hline Groups I-III & $80 \%$ \\
\hline Groups IV-V & $29 \%$ \\
\hline \multicolumn{2}{|l|}{ Foote et al (11) } \\
\hline$\leq 16 \mathrm{~mm}$ & $91 \%$ \\
\hline$>16 \mathrm{~mm}$ & $67 \%$ \\
\hline \multicolumn{2}{|c|}{ DeSutter et a (19) } \\
\hline$<6.5 \mathrm{~mm}$ & $91 \%$ \\
\hline $6.5-16 \mathrm{~mm}$ & $94.5 \%$ \\
\hline$>16 \mathrm{~mm}$ & $71.4 \%$ \\
\hline \multicolumn{2}{|c|}{ Hernandez et al (20) } \\
\hline$<5 \mathrm{~mm}$ & $87.5 \%$ \\
\hline $5.1-10 \mathrm{~mm}$ & $93 \%$ \\
\hline $10.1-15 \mathrm{~mm}$ & $71.5 \%$ \\
\hline$>15 \mathrm{~mm}$ & $50 \%$ \\
\hline
\end{tabular}

Table 2. Tumor control rates following EBRT in RB

\begin{tabular}{|c|c|c|}
\hline Series & $\begin{array}{l}\text { Local control rate } \\
\text { rate with EBRT } \\
\text { alone }(\%)\end{array}$ & $\begin{array}{l}\text { Overall ocular sur } \\
\text { vival with salvage } \\
\text { therapy (\%) }\end{array}$ \\
\hline Bedford et $\mathrm{al}^{23}$ & 52 & 84 \\
\hline Cassady et $\mathrm{al}^{9}$ & 49 & 69 \\
\hline Schipper et $\mathrm{al}^{24}$ & 41 & 81 \\
\hline Foote et $\mathrm{al}^{11}$ & 44 & 80 \\
\hline Hernandez et al $\left.\right|^{20}$ & 44 & 73 \\
\hline
\end{tabular}


Although quantification of the risk for second malignancies, and their relation with RT parameters could provide useful data for future treatment protocols, only a few studies have analysed the relationship between the dose of RT and risk of secondary tumors. Hawkins et al..$^{25}$ analysed 10.106 patients with a variety of childhood cancers with at least 3-year survival, and observed 90 second primary tumours (SPTs). For patients with hereditary RB, the authors reported 30fold higher incidence than the expected for overall SPTs, and over 400-fold for osteosarcomas. Interestingly the authors were unable to identify an excess risk for doses lower than $10 \mathrm{~Gy}$, emphasizing the importance of keeping the dose for bony structures at as low as possible levels. In another study, Wong et al. analysed $1604 \mathrm{RB}$ patients of which $60 \%$ were hereditary cases, and observed 99 SPTs in 190 patients. ${ }^{26}$ The cumulative incidence for SPT was $51.0 \% \pm$ $6.2 \%$ in hereditary cases and $5.0 \% \pm 3.0 \%$ in nonhereditary cases at 50 years of follow-up. Use of RT was found to be associated with increased risk of SPTs in hereditary and nonhereditary RBs with cumulative incidence rates of $58.3 \% \pm 8.9 \%$ and $26.5 \%$ \pm 10.7 , respectively. All but 2 of the 83 patients with diagnosis of second sarcomas were reported to be of those whom received RT. The authors concluded that the relative risk for soft tissue sarcoma was showing a stepwise incremental relationship with the dose of RT; but, this risk did not reach statistical significance at dose ranges between 5 to 9.9 Gy and 60 Gy or greater. Additional analysis revealed that, the risk for overall all sarcomas was significantly elevated at doses between 5 to 9,9 Gy and dose levels beyond. Le $\mathrm{Vu}$ et al. ${ }^{27}$ published the only study demonstrating the importance of fractionation. In this study, 4400 children with solid cancers those survived at least 3-year after treatment were analyzed. Starkly contrasting with others, authors found an excess risk of osteosarcoma for local doses ranging from 1 to $10 \mathrm{~Gy}$. Of note, the authors were able to demonstrate a trend $(\mathrm{p}=$ $0.10)$ for lower excess odds ratio per gray (EOR/Gy) for doses delivered in more than 20 fractions $(\mathrm{ERR} / \mathrm{Gy}=0.73)$ than for doses delivered in less than 20 fractions $(E R R / G y=2.4)$. Data from atomic bomb survivors or fluoroscopically examined tuberculosis patients also revealed that sarcomas have not been increased in populations exposed to much lower doses of ionizing radiation (dose, $<1 \mathrm{~Gy}$ ).

\section{ORBITAL GROWTH RETARDATION}

In children, an important dose-limiting toxicity of radiation therapy is the inhibition of skeletal growth by the damage to rapidly dividing cells located in the proliferative zone of the growth plates. ${ }^{16}$ Factors associated with the severity of RT-induced abnormalities in bone growth include age, growth potential, total dose, dose per fraction, beam energy, treated site, and treatment volume..$^{28-34}$

The clinical literature suggests a steeper dose-effect relationship particularly with the doses ranging from 15 to 30 Gy. In children, treated to entire spine for medulloblastoma, acute lymphoblastic leukaemia, and Hodgkin's disease, Probert and Parker ${ }^{35}$ showed growth arrest, which was strikingly noticeable in those receiving high doses ( $>35 \mathrm{~Gy}$ ) of axial skeletal irradiation. Similarly, in the study by Wilman ${ }^{36}$, severe growth retardation was reported in children who had received doses above 33 Gy. In another study, although facial asymmetry to some extend was notable at the doses above $26 \mathrm{~Gy}$, it was cosmetically significant in only three cases treated to dose levels of 30 Gy, 35 Gy, and 36 Gy through opposing lateral fields. ${ }^{37}$ Compared to non-irradiated controls, O Donovan et al..$^{38}$ observed significantly reduced linear bone growth, bone volume and density in animals having their orbital-zygomatic complexes irradiated to a dose of 25 or $35 \mathrm{~Gy}$. The critical dose cut off has been suggested to be $25 \mathrm{~Gy}$, below which development of significant growth abnormalities is extremely rare. In children with the diagnosis of leukemia, Sonis et al. ${ }^{39}$ found a dramatic difference in the severity of micrognathia in those receiving $24 \mathrm{~Gy}$ versus 18 Gy to their mandibula at the time of cranial irradiation.

Importance of age and amount of growth remaining at the time of RT are well established. Sensitivity to irradiation has been revealed to be $25 \%$ higher in children than adults. ${ }^{40}$ In the study by Oehmann et $\mathrm{al}^{41}$, the first growth spurts in the orbita was observed at ages between 6 and 8 years $(25 \%$ increase in volume). Likewise, Imhof et al. ${ }^{30}$ reported more damage to the orbital growth in children younger than 6 months of age $(\mathrm{p}<0.01)$.

Little is known about the importance of fractionation. However, both preclinical and clinical experience in hand suggest a correlation between fraction size and severity of injury to developing tissues, neces- 
sitating the exclusion of actively growing center in the bone from radiation fields. ${ }^{38}$ In rats, Eifel et al. ${ }^{16}$ reported an $\alpha / \beta$ ratio of approximately 4.47 for the growing bone, which is predictive of a favourable therapeutic gain with use of hyperfractionated schemes. In that study, authors also concluded that keeping fraction doses below 1 Gy would diminish the risk of impairment in bone growth.

\section{CHEMOREDUCTION}

The aim of chemoreduction is to reduce the irradiated volume of interest in an effort to increase the efficacy of RT while minimizing the visual damage. Although a number of agents including nitrogen mustard, triethylenemelamine, cyclophosphamide have been tried, only carboplatin, etoposid and vincristine gained the importance by achieving globe salvage rate of $85 \%$ in RE group I-IV. ${ }^{43}$ Although the main advantage of chemotherapy is to postpone EBRT after the age of 12 months, when both orbital growth and tumorigenesis appear less sensitive to radiation, as demonstrated by Wilson et al..$^{44}$, chemotherapy alone could be efficacious in only $8 \%$ of patients with $\mathrm{RB}$ at various stages of RB.

There is no prospective study comparing EBRT with chemotherapy. In one of the two retrospective studies, Hungerford et al. ${ }^{45}$ compared lens sparing EBRT and systemic chemotherapy in RE group I-III patients, and reported tumor control rates of $96 \%$ vs. 94\% for for EBRT and chemotherapy groups, respectively. With primary treatment only, a smaller proportion of eyes were classified as treatment successes in both groups (53\% for EBRT, 29\% for chemotherapy). Overall success rate of salvage treatment $93 \%$ for radiotherapy group and $91 \%$ for chemotherapy group. In the second series by Sussman et al. ${ }^{46}$, with chemotherapy, a significantly greater reduction in tumor volume at both 1 month (32\% versus $88 \%$, $\mathrm{p}=$ $0.004)$ and 2 month ( $19 \%$ versus $42 \%, p=0.04)$ of follow up were achieved. However, there was no difference at 12 month (9\% versus 6\%, $\mathrm{p}=0.76)$. There was no significant difference between groups regarding toxicity profile except for cataracts, which was higher in EBRT group.

\section{PLAQUE RADIATION THERAPY}

Plaque RT has also been used as the primary modality or adjuvant treatment option in the management of RB. Following the first experience of BRT by Foster-Moore and Scott's ${ }^{48}$ with radon seeds implanted into the tumor, a number of centers used episcleral plaque BRT with variety of isotopes. First, Stallard ${ }^{8}$ used Co-60 plaques in 104 tumors, and achieved tumor control with preserved eyes in 62 of them. Authors reported that failures were most common in cases with more than one quarter retinal involvement. Then, Ru-106, Au-198, I-191 plaques came into use in BRT of RB, however, I-125 gained the greatest interest because of its favorable physical properties such as low energy, adequacy of dose distribution, and relatively lower exposure of the uninvolved contralateral side of the eye, and decreased exposure to staff. Although tumor thickness is the determinant factor, usual total dose ranges between 40 to $50 \mathrm{~Gy}$ that is prescribed at the apex of the tumor.

Shields et al. published the results of an analysis including 208 tumors treated with primary or secondary plaque BRT using either I125, Ru106, Co60, or I192. ${ }^{49}$ Tumor control with plaque BRT was achieved in $92 \%$ after cryotherapy or laser photocoagulation, $\% 92$ after chemoreduction, $75 \%$ after EBRT and $66 \%$ after both chemoreduction and EBRT. Mean dose to lens, foveola, and optic disc were $9.82 \mathrm{~Gy}$, $29.63 \mathrm{~Gy}$, and $23.11 \mathrm{~Gy}$, respectively, and mean dose to apex and base of the tumor were $41.60 \mathrm{~Gy}$ and 15.45 Gy, respectively. Complication rates were as follows: nonproliferative retinopathy in $27 \%$, proliferative retinopathy in $15 \%$, maculopathy in $25 \%$, papillopathy in $26 \%$, cataract in $31 \%$, and glaucoma in $11 \%$, and they did not observe scleral necrosis. Plaque radiation therapy has advantages over to other local treatment modalities such as thermotherapy, chemothermotherapy, or laser photocoagulation. It can be used for tumors up to $16 \mathrm{~mm}$ and for the vitreous seeds are limited to quadrant of the tumor. If the seeds were diffuse then EBRT was advised.

In one retrospective study plaque BRT was compared with EBRT. ${ }^{50}$ Three treatment groups were identified: BRT, EBRT and the last group consisted patients those were initially treated by EBRT or enucleation and BRT was used for salvage (Table 3). BRT and EBRT were found to be equally effective, although there was higher rate of cataract in EBRT groups. However, because of study design, finding was not robust. Other 3 retrospective studies compared EBRT with local treatments. Table 4 summarises the main cha- 
Table 3. Results of study by Amendola et al (50), comparing brachytherapy and EBRT

\begin{tabular}{|c|c|c|c|c|}
\hline & Eye(s) treated & Eye(s) spared & Cataracts & Salvage treatment \\
\hline Treatment I & 25 eyes & $22 / 25$ & $2 / 22$ & $7 / 25$ \\
\hline Brachytherapy & (4 group IV-V) & & & \\
\hline Treatment II & 13 eyes & $11 / 13$ & $5 / 11$ & $2 / 13$ \\
\hline EBRT & (5 group IV-V) & & & \\
\hline Treatment III & 29 eyes & $15 / 29$ & $9 / 15$ & $14 / 29$ \\
\hline Salvage & (28 group V) & & & \\
\hline Brachytherapy & & & & \\
\hline
\end{tabular}

racteristics of these studies. Merill et al. (51) reported no significant difference between EBRT and local treatment for new and recurrent tumours, but the other 2 studies did not report statistical outcomes. ${ }^{52,53}$ In study reported by Messmer et al..$^{2}$, a similar proportion of patients in both treatment groups developed new and recurrent tumours (20\% and $27 \%$ for local treatment and EBRT, respectively) and recurrent tumours (26\% and $28 \%$ for local and EBRT treatment, respectively). However, it is difficult to make a meaningful comparison between these studies as patients characteristics, treatment protocols, and follow-up times varied widely.

\section{NOVEL TECHNIQUES OF THE EXTERNAL RADIOTHERAPY}

The management of RB has evolved gradually over the past 10 years. The treatment decision has shifted from enucleation and EBRT toward chemoreduction and focal conservative treatments. Current indications for EBRT include the followings:

- Second line treatment for group B and C eyes with remnant regressed type II and III tumors localized at the posterior pole involving the optic nerve head and macula in single eyes, and as the first line treatment for the same group B and C tumors

Table 4. Studies comparing local treatment (non-EBRT vs EBRT)

\begin{tabular}{|c|c|c|c|c|c|}
\hline \multirow[t]{2}{*}{ Reference } & \multirow{2}{*}{$\begin{array}{l}\text { Number of } \\
\text { Tumors }\end{array}$} & \multicolumn{2}{|c|}{ Tumors } & \multicolumn{2}{|c|}{ Mean latency for tumor development } \\
\hline & & Primary tumors & Recurrent tumors & Primary (Months) & Recurrent (Months) \\
\hline \multicolumn{6}{|l|}{ Merril et $a^{51}$} \\
\hline Non-EBRT & 9 & 11 & 11 & - & - \\
\hline EBRT & 15 & 7 & 7 & - & - \\
\hline \multicolumn{6}{|c|}{ Messmer et $\mathrm{al}^{52}$} \\
\hline Non-EBRT & 102 & 20 & 26 & 4 & - \\
\hline EBRT & 127 & 27 & 28 & 9 & - \\
\hline \multicolumn{6}{|c|}{ Hadjistilianou et $\mathrm{al}^{53}$} \\
\hline Non-EBRT & 7 & 12 in 6 eyes & 4 in 3 eyes & 7.6 & 11 \\
\hline EBRT & 16 & 5 in 3 eyes & 5 in 4 eyes & 9.5 & 10.6 \\
\hline
\end{tabular}


- First or second line whole eye treatment for group D eyes in bilateral RB

- Bone-sparing proton treatment of unilateral group D retinoblastoma

- Salvage therapy for diffuse vitreous and/or subretinal recurrence

- Adjuvant therapy for the enucleated orbit with involvement of optic nerve

- Extra-ocular and non-ocular retinoblastoma

With the introduction of chemoreduction, use of EBRT has been limited to the salvage therapy for the recurrent RB. However, with the evolution of novel techniques in RT, including stereotactic RT and proton therapy, the role of EBRT in the management of retinoblastoma has gained importance. These techniques allow more focused administration of RT while sparing much more the critical structures in the globe. In their study, Krasin et al..$^{54}$ evaluated IMRT versus conformal RT with en face electron technique and an anterior and lateral-wedged photon technique. Compared to combined photon/electron technique and conformal RT, they observed a more than onethird and $23 \%$ decrease in the dose to the bonny orbit with IMRT, respectively.

Stereotactic radiotherapy (SRT) is the other technique superior to conventional EBRT of RB. It has been successfully used for the RT of unilateral RB cases, particularly of small posterior tumors. ${ }^{55}$ With the use of SRT, radiation can be delivered to small sized posterior pole tumors with maximal sparing of the surrounding normal tissues. In a small study, Sahgal et al..$^{56}$ treated 6 eyes in 4 patients with focal tumor located at posterior pole. One of the patients was treated with whole-eye SRT due to vitreous seeding. In patients treated with focal SRT, median doses to the tumor, optic chiasm, brainstem, ipsilateral optic nerve, globe, lens, orbital bone, and contralateral orbital bone were $41.92,0.25,0.07,9.98,19.11,3.74,6.73$ and $2.31 \mathrm{~Gy}$, respectively. In another study comparing SRT with the standard EBRT in 2 cases with bilateral RB, Higgins et al..$^{57}$ found the normal tissue complication rate reduced from $\geq 95 \%$ to $\leq 16 \%$ with SRT.

\section{CONCLUSION}

The most critical issue in the EBRT of RB is to deliver minimal dose to bony orbit. Although EBRT yields effective control of tumor and long-term survival, development of SPTs in the extra-ocular structures restricts its role in the management of $\mathrm{RB}$, thus necessitating the evolution of novel techniques to either avoid or minimize the irradiation of extra-ocular structures. Recently, with excellent range of dose in depth and relatively low integral doses, proton therapy appears to offer certain theoretical advantages over other modalities including SRT and IMRT.

\section{REFERENCES}

1. Knudson AG. Mutation and cancer: Statistical study of retinoblastoma. Proc Natl Acad Sci USA 68: 820-823, 1971.

2. Hethcote HW, Knudson AG. Model for incidence of embryonal cancers: Application to retinoblastoma. Proc Natl Acad Sci USA 75: 2443-2457, 1978.

3. De Potter P. Current treatment of retinoblastoma. Curr Opin Ophtalmol 13: 331-336, 2002.

4. Dondey J, Staffieri S. Retinoblastoma in victoria, 19762000 : changing management trends and outcomes. Clin Experiment Ophthalmol 32: 354-359, 2004.

5. Harbour J. What is the best treatment for retinoblastoma. Am J Ophthalmol 138: 471-473, 2004.

6. Shields C, Shield J. Recent developments in the management of retinoblastoma. J Pediatr Ophthalmol Strabismus 36: 8-18, 1999.

7. Abramson PH, Ellsworth R, Rosenblatt M. Retreatment of retino-blastoma with external beam irradiation. Arch Ophthalmol 100: 1257-1260, 1982.

8. Stallard HB. Pathological study of retinoblastoma treated by radon seeds and radium disc; William McKenzie memorial lecture. $\mathrm{Br} J$ Ophthalmol 36: 245-254, 1952.

9. Cassady JR, Sagerman RH, Tretter P, Ellsworth RM: Radiation therapy in retinoblastoma. Radiology 93: 405-409, 1969.

10. Thompson TW, Small RC, Stein JJ. Treatment of retinoblastoma. Am J Roentgenol 14: 16-23, 1972.

11. Foote RL, Garretson BR, Schomberg PJ. External beam irradiation for retinoblastoma: patterns of failure and dose-response analysis. Int J Radiat Oncol Biol Phys 16: 823-830, 1989.

12. Hayden BC, Murray TG, Cicciarelli N. Hyperfractionated external beam radiation therapy in the treatment of murine transgenic retinoblastoma. Arch Ophthalmol 120: 353-359, 2002. 
13. Parsons JT, Fitzgerald CR, Hood Cl. The effects of irradiation on the eye and optic nerve. Int $\mathrm{J}$ Radiat Oncol Biol Phys 9: 609-622, 1983.

14. Egawa S, Tsukiyama I, Yasuyuki A. Supression of bony growth of the orbit after radiotherapy of retinoblastoma. Radiat Med 5: 207-221, 1987.

15. Abramson DH, Du T, Beaverson KL. (Neonatal) retinoblastoma in the first month of life. Arch Opthalmol 120: 738-742, 2002.

16. Eifel PJ, Donaldson SS, Thomas PR. Response of growing bone to irradiation: a proposed late effects scoring system. Int J Radiat Oncol Biol Phys 31: 13011307, 1995.

17. McCormick B, Ellsworth R, Abramson D. Radiation therapy for retinoblastoma: comparison of results with lens-sparing versus lateral beam techniques. Int J Radiat Oncol Biol Phys 15: 567-74, 1988.

18. Egbert PR, Donaldson SS, Moazed K. Visual results and ocular complications following radiotherapy for retinoblastoma. Arch. Ophthalmol 96: 1826-1830, 1978.

19. De Sutter E, Havers W, Hopping W. The prognosis of retinoblastoma in terms of globe saving treatment. A computer assisted study. Part I. Ophthal Paediatr. Genet 8: 77-84, 1987.

20. Hernandez JC, Brady LW, Shields JA. External beam radiation for retinoblastoma: results, pattern of failure, and a proposal for treatment guidelines. Int $J$ Radiat Oncol Biol Phys 35 : 125-32, 1996.

21. Abramson DH, Beaverson KL, Chang ST. Outcome of following initial external beam radiotherapy in patients with Reese-Ellsworth group Vb retinoblastoma. Arc Ophthalmol 122: 1316-23, 2004.

22. Abramson DH, Frank CM. Second nonocular tumors in survivors of bilateral retinoblastoma: a possible age effect on radiation-related risk. Ophthalmology 105: 573-9, 1998.

23. Bedford MA, Bedotto C, Macfaul PA. Retinoblastoma. A study of 139 cases. Br J Ophthalmol 55: 19-27, 1971.

24. Schipper J. An accurate and simple method for megavoltage radiation therapy of retinoblastoma. Radiother Oncol 1: 31-41, 1983.

25. Hawkins MM, Draper GJ, Kingston JE. Incidence of second primary tumours among childhood cancer survivors. Br J Cancer 56: 339-347, 1987.

26. Wong FL, Boice JD Jr, Abramson DH. Cancer incidence after retinoblastoma. Radiation dose and sarcoma risk. JAMA 278: 1262-1267, 1997.

27. Le Vu B, de Vathaire F, Shamsaldin A. Radiation dose, chemotherapy and risk of osteosarcoma after solid tumours during childhood. Int $\mathrm{J}$ Cancer 77: 370-377, 1998.

28. Smith R, Davidson JK, Flatman GE. Skeletal effects of orthovoltage and megavoltage therapy following treatment of nephroblastoma. Clin Radiol 33: 601-13, 1982.
29. Guyuron B, Dagys AP, Munro IR. Effect of irradiation onfacial growth: 7- to 25- year follow-up. Ann Plast Surg 11: 423-427, 1983.

30. Imhof SM, Mourits MP, Hofman P. Quantification of orbital and mid-facial growth retardation after megavoltage external beam irradiation in children with retinoblastoma. Ophthalmology 103: 263-268, 1996.

31. Guyuron B. The hour glass facial deformity. J Craniomaxillofac Sur 18: 187-191, 1990.

32. Larson DL. Long-term effects of radiation therapy in the head and neck. Clin Plast Surg 20: 485-490, 1993.

33. Ju DM, Moss M, Crikelair GF. Effect of radiation on the development of facial structures in retinoblastoma cases. Am J Surg 106: 807-815, 1963.

34. Yue NC, Benson ML. The hourglass facial deformity as a consequence of orbital irradiation for bilateral retinoblastoma. Pediatr Radiol 26: 421- 423, 1996.

35. Probert J,Parker $B$. The effects of radiation therapy on bone growth. Radiology 114: 155-162;1975.

36. Willman K, Cox R, Donaldson S. Radiation induced height impairment in pediatric Hodgkin's disease. Int $\mathrm{J}$ Radiat Oncol Biol Phys 28: 85-92;1994.

37. Fontanesi J, Pratt CB, Kun LE. Treatment outcome and dose-response relationship in infants younger than 1 year treated for retinoblastoma with primary irradiation. Med Pediatr Oncol 26: 297-304, 1996.

38. O'Donovan DA, Yeung I, Zeman V. Radiation-induced craniofacial bone growth inhibition: development of an animal model. J Craniofac Surg 12: 533-543, 2001.

39. Sonis A, Tarbell N, Valachovic R. Dentofacial development in long-term survivors of acute lymphoblastic leukemia. A comparison of three treatment modalities. Cancer 66: 2645-2652;1990.

40. Nwoku AL, Koch $\mathrm{H}$. Effect of radiation injury on the growing face. J. Maxillofac Surg 3: 28-34, 1975.

41. Oehmann G. Volumen der orbita und flachenbestimmungen ihrer bauteile wahrend der postnatalen entwicklung. Universitat Wurzberg. Thesis, Wrzberg 1975.

42. Eifel P, Sampson C, Tucker S. Radiation fractionation sensitivity of epiphysial cartilage in a weanling rat model. Int J Radiat Oncol Biol Phys 19: 661-664, 1990.

43. Shields CL, Honavar SG, Meadows AT. Chemoreduction plus focal therapy for retinoblastoma: factors predictive of need for treatment with external beam radiotherapy or enucleation. Am J Ophthalmol 133: 657-664, 2002.

44. Wilson MW, Galindo CR, Haik BG. Multiagent chemotherapy as neoadjuvant treatment for multifocal intraocular retinoblastoma. Ophthalmology. 108: 21062115, 2001.

45. Hungerford JL, Toma NM, Plowman PN. External beam radiotherapy for retinoblastoma: I. Whole eye technique. Br J Ophthalmol 79: 109-11, 1995.

46. Sussman DA, Escalona-Benz E, Benz MS. Comparison of retinoblastoma reduction for chemotherapy vs external beam radiotherapy. Arch Ophthalmol 121: 979-84, 2003. 
47. Shields CL, Mashayekhi A, Cater J. Chemoreduction for retinoblastoma:analysis of tumor control and risks for recurrence in 457 tumors. Am J Ophthalmol 138: 329-37, 2004.

48. Foster-Moore R, Scott RS: Clinical and pathological report of bilateral glioma retina. Proc R Soc Med 22: 39-50, 1929.

49. Shields CL, Shields JA, Cater J. Plaque radiotherapy for retinoblastoma: Long-term tumor control and treatment complications in 208 tumors. Ophthalmology 108: 2116-21, 2001.

50. Amendola BE, Lamm FR, Markoe AM. Radiotherapy of retinoblastoma. A review of 63 children treated with different irradiation techniques. Cancer 66: 21-6, 1990.

51. Merill PT, Buckley EG, Halperin EC. New and recurrent tumors in germinal retinoblastoma: is there a treatment effect? Ophthalmic Fenet 17: 115-118, 1996.

52. Messmer EP, Saverwein W, Heinrich T, Hopping W, Klueter-Reckmann D, Bornfeld N. New and recurrent tumor foci following local treatment as well as external beam radiation in eyes of patients with hereditary retinoblastoma. Graefe's Arch Clin Exp Ophthalmol 228: 426-431, 1990.

53. Hadjistilanou T, Greco G, Frezzoti R. Recurrent and new tumors during conservative treatment of bilateral retinoblastoma. Ophthal Paediatr Genet 12: 79-84, 1991.

54. Krasin MJ, Crawford BT, Zhu Y. Intensity-modulated radiation therapy for children with intraocular retinoblastoma: potential sparing of the bony orbit. Clin Oncol 16: 215-22, 2004.
55. Kooy HM, Dunbar SF, Tarbell NJ. Adaptation and verification of the relocatable Gill-Thomas-Cosman frame in stereotactic radiotherapy. Int $\mathrm{J}$ Radiat Oncol Biol Phys 30: 685-691, 1994.

56. Sahgal A, Millar BA, Michaels H. Focal stereotactic external beam radiotherapy as a vision-sparing method for the treatment of peripapillary and perimacular retinoblastoma: preliminary results. Clin Oncol 18: 628-634, 2006.

57. Higgins PD, Gerbi BJ, Macedon M. Fractionated stereotactic radiotherapy for pediatric patients with retinobalastoma. J Appl Clin Med Phys 7: 9-17, 2006.

\section{Correspondence}

Dr. Berrin PEHLIVAN

Başkent Üniversitesi Tıp Fakültesi

Radyasyon Onkolojisi Anabilim Dalı

Adana / TURKEY

Tel: (+90.532) 4024727

email: berrin_pehlivan@yahoo.com 